\title{
Protein digestion in the intestine of sheep
}

\author{
By D. BEN-GHEDALIA, H. TAGARI AND A. BONDI \\ Department of Animal Nutrition and Agricultural Biochemistry, \\ The Hebrew University, Faculty of Agriculture, Rehovot, Israel \\ AND A. TADMOR \\ Kimron Veterinary Research Institute, Beth Dagan, Israel
}

(Received I 8 November 1972-Accepted $26 \not{7 u l y}$ 1973)

\begin{abstract}
I. The rate of flow of digesta along the intestinal tract, and particularly the changes occurring in proteins during their passage through the intestine were determined in six rams; each animal was fistulated with three cannulas which involved six different sites of the intestine. $\mathrm{Cr}_{2} \mathrm{O}_{3}$ was used as a marker substance to measure the rate of flow of the digesta.

2. In the sections of the intestine from $I$ to $15 \mathrm{~m}$ posterior to the pylorus the amounts of water, dry matter and total nitrogen decreased gradually as a result of their absorption through the intestinal wall. The region of the intestine situated at a distance of $7-15 \mathrm{~m}$ from the pylorus was more active with respect to the absorption of $N$, whereas water and dry matter were adsorbed to a greater extent in the region from $x$ to $7 \mathrm{~m}$ from the pylorus.

3. The only part of the intestine in which substantial increases of water, dry matter and total $\mathrm{N}$ were found was the section immediately distal to the pylorus, and these increases were caused by the inflow of bile, and pancreatic and duodenal juices. The net increase found beyond the entry of the common bile duct was $2.7 \mathrm{~g}$ protein $\mathrm{N}$ and $2.0 \mathrm{~g}$ non-protein $\mathrm{N}$ $(\mathrm{NPN}) / 24 \mathrm{~h}$.

4. The activities of trypsin, chymotrypsin and carboxypeptidase $\mathrm{A}$ and the ratio $\alpha-\mathrm{NH}_{2}-$ NPN:protein $N$ increased from the pylorus up to a distance of $7 \mathrm{~m}$ and decreased again from this point to a distance of $\mathrm{x} 5 \mathrm{~m}$ from the pylorus.

5. In the sections of the intestine between $I$ and 3 and between 3 and $7 \mathrm{~m}$ distant from the pylorus the extent of proteolysis exceeded considerably that of absorption of amino acids through the intestinal wall. This was concluded from the decrease in the rate of flow of protein amino acids (by $3 \mathrm{I} \%$ between $\mathrm{I}$ and $3 \mathrm{~m}$ distant from the pylorus and by $34 \%$ between 3 and $7 \mathrm{~m}$ ) and the simultaneous increase in non-protein amino acids (by $20 \%$ in the region between 1 and $3 \mathrm{~m}$ ) or no change in non-protein amino acids (between 3 and $7 \mathrm{~m}$ ).

6. The relatively greater decrease in non-protein amino acids (by $57 \%$ ) compared with that of protein amino acids (by $41 \%$ ) occurring in the section 7 to $15 \mathrm{~m}$ distant from the pylorus showed that this is an area of most intensive absorption of amino acids.

7. In the lower section of the intestine, from 15 to $25 \mathrm{~m}$ distant from the pylorus, the total amount of amino acids showed almost no change; probably a net effect of loss and gain of amino acids mainly due to microbial activities. Increases in the dehydrogenase activity suggested enhancement of bacterial activity in this lower region of the intestine.

8. The supply of essential amino acids to the tissues of sheep is improved, compared with the amino acid composition of the diet, as the result of ruminal biosynthesis of essential amino acids and ruminal degradation of non-essential amino acids and preferential absorption of essential amino acids through the intestinal wall, particularly in the section of most intensive absorption, $7^{-1} 5 \mathrm{~m}$ distant from the pylorus.
\end{abstract}

Whereas the transformations of the nitrogenous food components occurring in the reticulo-rumen of ruminant animals have been thoroughly studied, very few quantitative results are available on the course of digestion of proteins in the intestine (Kay, 1969). Since extensive digestion of nitrogen compounds takes place in the intestine and the greater part of the $\mathrm{N}$-containing metabolites is absorbed through the intestinal wall, a study of intestinal digestion in ruminants is of interest. 
Table 1. Position of intestinal cannulas in the rams nos. 1-6

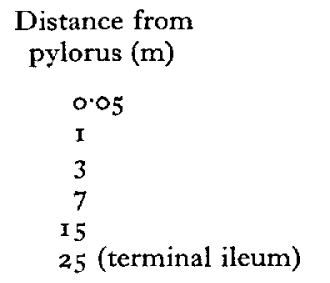

$\begin{array}{ccc}\text { No. I } & \text { No. } 2 & \text { No. } 3 \\ \cdot & + & + \\ \dot{+} & + & + \\ + & : & + \\ + & + & :\end{array}$

No. 4
+
.
$\dot{+}$
+

$\begin{array}{cc}\text { No. } 5 & \text { No. } 6 \\ + & . \\ + & + \\ + & + \\ \dot{ } & +\end{array}$

* Rams nos. $\mathrm{I}$ and 6 rejected these cannulas at the beginning of the experiment.

Whereas a periodical influx of digesta into the intestine is typical for the simplestomached animal, the passage of the digesta from the reticulo-rumen and omasum is a continuous process. Hence the digesta that reach the intestine in ruminants are of more uniform composition and less dependent on the kind of food ingested than in simple-stomached animals. These digesta consist to a great extent of microbial protein and contain only very small amounts of carbohydrates, since most of the latter have been digested and their metabolites have been absorbed in the rumen. Therefore the digestive processes in the intestinal tract of simple-stomached and ruminant animals may differ. In this work the rate of passage of digesta, and particularly of their nitrogenous constituents, such as non-protein $\mathrm{N}(\mathrm{NPN}), \alpha-\mathrm{NH}_{2}-\mathrm{N}, \mathrm{NH}_{3}$ and individual amino acids through the different regions of the intestine has been studied. The changes occurring in nitrogenous constituents during passage through the intestine have been examined, the activity of proteolytic enzymes in the different parts of the intestine has been assessed, and the extent of the absorption of the nitrogenous metabolites from the different sections of the intestinal wall has been determined.

Furthermore, in order to examine the possible involvement of micro-organisms in $\mathrm{N}$ interactions occurring in the intestine, dehydrogenase activity reflecting microbial biochemical capacity was assayed in the samples of digesta.

\section{EXPERIMENTAL}

\section{Animals}

Six Awassi rams, I-I.5 years old and weighing 50-60 kg, were used. Each animal was equipped with 3 T-type Perspex cannulas inserted at different sites of the small intestine; the positions of the cannulas are given in Table $\mathrm{I}$.

The cannulas consisted of two parts: a straight barrel, $45 \mathrm{~mm}$ long, was joined with a screw to a gutter-shaped internal flange, $42 \mathrm{~mm}$ long; the flange was inserted into the intestine and the barrels exteriorized through the abdominal wall. The barrels were closed by a combined cap and core which prevented accumulation of digesta in the barrel between sampling times. Two kinds of cannula were used. The first type with a barrel of $\mathrm{Ir}^{\circ} 5 \mathrm{~mm}$ internal diameter and with an internal flange of $\mathrm{I}_{3} \mathrm{~mm}$ internal diameter was inserted into the intestine at $0.05 \mathrm{~m}$ distance from the pylorus and into the terminal ileum. The second type with a barrel of $9.5 \mathrm{~mm}$ internal diameter and a flange of $10.5 \mathrm{~mm}$ internal diameter was inserted at the middle sites of the intestine. 
Table 2. Composition $(\mathrm{g} / \mathrm{kg})$ of the feedstuffs

\begin{tabular}{|c|c|c|c|c|c|c|}
\hline Feedstuff & $\begin{array}{c}\text { Dry } \\
\text { matter }\end{array}$ & $\begin{array}{l}\text { Crude } \\
\text { protein }\end{array}$ & $\begin{array}{c}\text { Diethyl } \\
\text { ether extract }\end{array}$ & $\begin{array}{l}\text { Crude } \\
\text { fibre }\end{array}$ & Ash & $\begin{array}{l}\text { Nitrogen-free } \\
\text { extract }\end{array}$ \\
\hline $\begin{array}{l}\text { Concentrate } \\
\text { mixture }\end{array}$ & 890 & 100 & $24 \cdot 8$ & 124 & $72 \cdot 5$ & 568 \\
\hline $\begin{array}{l}\text { Vetch hay } \\
\quad \text { (Vicia sativa } L .)\end{array}$ & 885 & 144 & $\times 8.0$ & 273 & $1120^{\circ}$ & $33^{8}$ \\
\hline
\end{tabular}

* Contained (per kg) $250 \mathrm{~g}$ barley, $250 \mathrm{~g}$ maize, $250 \mathrm{~g}$ wheat, $150 \mathrm{~g}$ cottonseed hulls, $50 \mathrm{~g}$ cottonseed meal, $5 \circ \mathrm{g}$ mineral mixture, $1200 \mu \mathrm{g}$ retinol and $10 \mu \mathrm{g}$ ergocalciferol.

Table 3. Amino acid content (mmollkg) of the feedstuffs

$\begin{array}{lrr}\text { Amino acid } & \begin{array}{c}\text { Vetch hay } \\ \text { (Vicia sativa L.) }\end{array} & \text { Concentrate } \\ \text { Essential: } & & \\ \text { Threonine } & 42 \cdot 9 & 26 \cdot 5 \\ \text { Valine } & 76 \cdot 5 & 51 \cdot 0 \\ \text { Methionine } & 9 \cdot 9 & 5 \cdot 8 \\ \text { Isoleucine } & 39 \cdot 8 & 29 \cdot 2 \\ \text { Leucine } & 62 \cdot 7 & 64 \cdot 5 \\ \text { Phenylalanine } & 43 \cdot 2 & 31 \cdot 8 \\ \text { Lysine } & 40 \cdot 2 & 22 \cdot 4 \\ \text { Histidine } & 15 \cdot 7 & 1 \times 4 \\ \text { Arginine } & 30 \cdot 8 & 27 \cdot 3 \\ \text { Non-essential: } & & \\ \text { Aspartic acid } & 109 \cdot 0 & 54 \cdot 3 \\ \text { Serine } & 49 \cdot 4 & 35 \cdot 9 \\ \text { Glutamic acid } & 82 \cdot 4 & 123 \cdot 0 \\ \text { Proline } & 85 \cdot 8 & 65 \cdot 5 \\ \text { Glycine } & 92 \cdot 5 & 59 \cdot 2 \\ \text { Alanine } & 70 \cdot 3 & 66 \cdot 3 \\ \text { Cystine }+ \text { cysteine } & 4 \cdot 6 & 9 \cdot 4 \\ \text { Tyrosine } & 42 \cdot 4 & 22 \cdot 6\end{array}$

The animals recovered quickly and returned to normal food consumption within a month after the operation; the experiment began 3 months later.

Rams nos. I and 6 rejected the cannulas inserted at $7 \mathrm{~m}$ distance from the pylorus at the beginning of the experiment. The rejection was accompanied by a slight inflammation, after which the site of rejection healed up within 2 weeks, and the experiment, which had been interrupted, began again.

The total length of the small intestine was measured in rams nos. $1,2,4$ and 6; it was $25 \pm \mathrm{I} \cdot 2 \mathrm{~m}$. Very similar values for the length of the intestine have been found for Suffolk Cross and Scottish Blackface sheep by T. E. C. Weekes and R. M. Campbell at the Rowett Research Institute (private communication from Dr Margaret I. Chalmers).

\section{Feeding}

Each animal received a daily ration consisting of $400 \mathrm{~g}$ vetch hay (Vicia sativa L.) and $600 \mathrm{~g}$ concentrate mixture. Feeds were given in equal amounts twice daily at 07.30 and I 9.30 hours and were completely consumed. The composition of these feeds is given in Table 2. Water was freely available. During the experiment the rams were 
Table 4. Daily faecal recoveries of $\mathrm{Cr}_{2} \mathrm{O}_{3}$ given arally as a component of paper to sheep given three different rations

$$
\text { Ration (g dry faeces/sheep) }
$$

$\begin{array}{ll}\text { A } & 301 \\ \text { B } & 335 \\ \text { C } & 338\end{array}$

\begin{tabular}{|c|c|}
\hline \multicolumn{2}{|c|}{$\mathrm{Cr}_{2} \mathrm{O}_{3}$ recovery } \\
\hline $\mathrm{g} / \mathrm{d}$ & $\begin{array}{c}\text { As ratio of intake } \\
\text { mean }\end{array}$ \\
\hline 2.068 & 1.02 \\
\hline $2 \cdot 008$ & 0.99 \\
\hline$I \cdot 988$ & 0.98 \\
\hline & 0.04 \\
\hline
\end{tabular}

SEMT

housed in individual pens. Chromic oxide ( $\mathrm{I}$ g) impregnated into paper was given orally twice daily before feeding. The amino acid content of the feedstuffs ingested is given in Table 3 .

\section{Recovery of $\mathrm{Cr}_{2} \mathrm{O}_{3}$ and its use for calculating the flow rate of digesta}

A separate experiment was done in order to ensure quantitative recovery of $\mathrm{Cr}_{2} \mathrm{O}_{3}$ from the faeces. Nine I-year-old rams (average weight $55 \mathrm{~kg}$ ) were used. Three rations were used, each being given to three animals. The rations and the $\mathrm{Cr}_{2} \mathrm{O}_{3}$ were given for a preliminary period of $5 \mathrm{~d}$ before the start of the collection period, which lasted for $12 \mathrm{~d}$. The virtually complete recovery of $\mathrm{Cr}_{2} \mathrm{O}_{3}$ in the faeces (Table 4 ) is in agreement with the findings of Corbett, Greenhalgh, McDonald \& Florence (Ig6o) and of MacRae \& Armstrong (1969).

Klooster, Rogers \& Sharma (1969) and Corse \& Sutton (I97I) compared the flow of digesta measured by direct continuous collections through re-entrant cannulas with indirect measurements based on the concentration of $\mathrm{Cr}_{2} \mathrm{O}_{3}$ in spot samples of the digesta. According to these authors there was very little difference between the flow rate estimated by either method. In this work, calculation of the flow rate was based on spot sampling with $\mathrm{Cr}_{2} \mathrm{O}_{3}$ as indicator.

\section{Sampling technique}

The frequency of sampling and size of samples withdrawn had to be limited in order to avoid influencing the flow rate. Sampling of faeces and digesta began at the rectum and continued upwards through the terminal ilcum to the proximal duodenum. Before the samples were collected through the cannulas the animals were accustomed for I d to the sampling procedure. Samples, each of $25 \mathrm{ml}$ digesta, were withdrawn through each cannula six times daily for 4 successive $d, r, 3,5,7,9$ and II $h$ after the morning feed. The samples obtained on the 4 successive $\mathrm{d}$ from each cannula were pooled for each sheep separately and kept frozen at $-20^{\circ}$ until analysis. Four or five samples were obtained daily from the terminal ileum cannulas. The flow of digesta through the ileum was characterized by its irregularity, in contrast with the virtually continuous flow through the duodenum. Sometimes there were no digesta present at the site of the ileal cannulas and it was impossible to take samples from this site.

Total $\mathrm{N}, \mathrm{N}$-containing fractions, and $\mathrm{Cr}_{2} \mathrm{O}_{3}$ were determined in the pooled samples. 
Portions of these samples were freeze-dried for determination of the dry-matter content.

At the end of the sampling period, samples were taken simultaneously from all cannulas during $\mathrm{I} \mathrm{d}, \mathrm{I}, 3,5,7$ and $9 \mathrm{~h}$ after the morning feed. The samples obtained after each time-interval from all sheep were pooled and used for determination of $\mathrm{pH}$. Activities of trypsin ( $\left.E C_{3} \cdot 4 \cdot 4.4\right)$, chymotrypsin $\left(E C_{3} \cdot 4 \cdot 4 \cdot 5\right)$ and carboxypeptidase $\mathrm{A}\left(E C_{3.4 .2 . \mathrm{I})}\right.$ were measured in the pooled digesta samples taken $\mathrm{r}, 5$ and $9 \mathrm{~h}$ after the morning feed.

For determination of amino acids, digesta samples of $25 \mathrm{ml}$ each were withdrawn from three rams through each cannula six times daily on 4 successive d. The samples obtained on the 4 successive $d$ from the three sheep were pooled separately for each site of cannulation.

Samples of digesta for the determination of dehydrogenase activity were removed from three rams through each cannula, three times on $\mathrm{I} d, \mathrm{I}, 5$ and $9 \mathrm{~h}$ after the morning feed. The samples taken from all cannulas were pooled separately for cach sampling time.

\section{Analytical procedures}

$\mathrm{Cr}_{2} \mathrm{O}_{3}$ was determined by the method of Stevenson \& de Langen (1960). Total $\mathrm{N}$ in digesta and faeces was measured by the Kjeldahl method. NPN was determined by the micro-Kjeldahl method in the supernatant fraction of digesta separated by precipitation with trichloroacetic acid (TCA) solution ( $5 \circ \mathrm{g} / \mathrm{l})$.

Ammonia was determined with a Technicon AutoAnalyzer (Technicon Instrument Co. Ltd) by the method of Clare \& Stevenson (I964).

Free $\alpha-\mathrm{NH}_{2}-\mathrm{N}$ was measured in the TCA supernatant fraction of the digesta and faeces by the colorimetric ninhydrin procedure (Rosen, I957). For determination of total $\alpha-\mathrm{NH}_{2}-\mathrm{N}$ in NPN, a pooled sample from each site of cannulation was taken from three sheep and protein was precipitated with TCA solution ( $50 \mathrm{~g} / 1)$. After removal of TCA by extraction with diethyl ether a portion $(5 \mathrm{ml})$ of the supernatant fraction was freeze-dried and the dry residue hydrolysed by boiling in $6 \mathrm{M}-\mathrm{HCl}$ (constant boiling point) for $22 \mathrm{~h}$ at $110^{\circ}$ under reduced pressure. The hydrolysate was dried and the $\alpha-\mathrm{NH}_{2}-\mathrm{N}$ determined by the ninhydrin method.

For the determination of individual free amino acids (non-protein amino acids) samples were prepared similarly. Before hydrolysis, norleucine was added as internal standard. After hydrolysis, $\mathrm{HCl}$ was removed on a rotary evaporator under reduced pressure at $60^{\circ}$ and the residue dissolved in $0.2 \mathrm{M}$-citrate buffer, $\mathrm{pH} 2 \cdot 2$. Individual amino acids were determined by column chromatography using an amino acid analyzer, Bio-Cal, $\mathrm{BC}-200$.

For the determination of individual amino acids (total amounts) in feeds, digesta and faeces, the samples were freeze-dried, ground in a hammermill and passed through a I mm sieve; hydrolysis and determination of amino acids were as described above. $\mathrm{pH}$ was measured with a Beckman portable $\mathrm{pH}$ meter immediately after sampling.

The pooled samples used for determination of trypsin and chymotrypsin activitics were kept in crushed ice and centrifuged at $70000 \mathrm{~g}$ for $15 \mathrm{~min}$ at $2^{\circ}$. Trypsin, 
Table 5. Mean flow rates of total digesta, water and dry matter and $p H$ range of intestinal contents of three sheep sampled at different sites (dry matter ingested: $37-82 \mathrm{~g} / \mathrm{h}$ )

Distance of site
from pylorus (m)
0.05
I
3
$7 \dagger$
15
25 (terminal ileum)
Residual sD
SE of difference between
adjusted means:
Least value
Greatest value

Greatest value

\section{Effects of rams}

Effects of cannulas
Adjusted flow-rate mean $(\mathrm{g} / \mathrm{h})$

$\begin{array}{cccc}\text { Digesta } & \text { Water } & \text { Dry matter } & \begin{array}{c}\mathrm{pH} \\ \text { (range) }\end{array} \\ 51 \mathrm{I} & 487 & 23 \cdot 8 & 2 \cdot 60-3 \cdot 00 \\ 555 & 526 & 29 \cdot 1 & 3 \cdot 54-4 \cdot 65 \\ 433 & 408 & 24 \cdot 4 & 4 \cdot 1 \mathrm{I}-5 \cdot 15 \\ 291 & 270 & 20 \cdot 1 & 5 \cdot 95-7 \cdot 02 \\ 205 & 187 & 17 \cdot 8 & 7 \cdot 80-8 \cdot 15 \\ \text { I8I } & 162 & 18 \cdot 5 & 7 \cdot 70-8 \cdot 22 \\ 37.9 & 37.3 & 1 \cdot 4 & \\ & & & \\ 34.0 & 33.5 & 1 \cdot 3 & \\ 59.3 & 58 \cdot 4 & 2 \cdot 2 & \end{array}$

Significance of the factors

NS, not significant. *** $P<0.01 . * * * P<0.001 .+$ One sheep only.

chymotrypsin and carboxypeptidase $A$ activities in the supernatant fraction were measured titrimetrically with benzoyl-x-arginine ethylester hydrochloride, $N$-acetylL-tyrosine ethylester (Neurath \& Schwert, 1950) and hippuryl-pL-phenyl-lactic acid (Marchaim \& Kulka, 1967) respectively, as substrates, using a Radiometer-Copenhagen $\mathrm{pH}$-stat with automatic titrator I I. The reaction was carried out at $38^{\circ} ; \mathrm{r} \mu \mathrm{mol}$ substrate hydrolysed/min was defined as one unit of activity.

Dehydrogenase activity of the digesta was determined with triphenyltetrazolium chloride by the method of Tagari, Dror, Ascarelli \& Bondi (1964) as modified by Dror, Tagari \& Bondi (1970).

\section{Statistical analysis}

An 'incomplete block' analysis was used in order to compare the results obtained at six sites on the basis of samples taken from two or three cannulas in each of six rams. Because the design was not balanced, the standard error of the difference between the adjusted means is not the same for each pair of sites. The least and greatest values are given in Tables 5 and 6 . The residual standard deviation is also given as a measure of the variability of the measured values.

\section{RESULTS}

\section{Changes occurring in the digesta along the intestinal tract}

It is unfortunate that samples taken $7 \mathrm{~m}$ distant from the pylorus were available from only one animal, and this should be borne in mind when changes spanning this region are considered.

Water, dry matter and total $N$. The rates of flow per h of digesta dry matter $(\mathrm{g} / \mathrm{h})$, water, total $\mathrm{N}$ and $\mathrm{N}$-containing fractions through the different sections of the intestine 
Table 6. Amounts (adjusted means) $(\mathrm{mg} / \mathrm{h})$ of nitrogen and of nitrogenous components in digesta of three sheep, sampled at different sites of the intestinal tract and excreted in faeces ( $N$ ingested in food: $785 \mathrm{mg} / \mathrm{h}$ )

Distance of site
from pylorus (m)
0.05
I
3
$7 \dagger$
I 5
$\mathbf{2 5}$ (terminal ileum)
Raeces
Residual sD
SE of difference between
adjusted means:
Least value
Greatest value

Effects of rams

Effects of cannulas

$\begin{array}{cc} & \\ \text { Total N } & \text { Non-protein N } \\ 743 & 254 \\ 951 & 320 \\ 828 & 277 \\ 810 & 281 \\ 449 & 150 \\ 383 & 102 \\ 296 & \\ 76.2 & 11 \cdot 7 \\ & \\ 68.5 & 10.5 \\ 119.3 & 18.3\end{array}$

Significance of the factors

\begin{tabular}{rccc}
\multicolumn{3}{c}{$\alpha-\mathrm{NH}_{2}-\mathrm{N}$} & \\
Total & Bound & Free & Ammonia N \\
$18 \mathrm{I}$ & 123 & 62 & 53 \\
199 & 138 & 68 & 64 \\
248 & 175 & 75 & 55 \\
237 & 127 & 120 & 52 \\
105 & 22 & 75 & 29 \\
57 & 20 & 31 & 23 \\
& & 13.5 & \\
& & $16 \cdot 0$ & $5 \cdot 1$ \\
& & & \\
& & & \\
& & & \\
& & 25.4 & \\
& & &
\end{tabular}

NS, not significant.

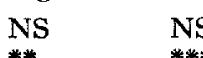

*** ****
NS
NS

**
** $P<0.01$. *** $P<0.001 .+$ One sheep only.

are presented in Tables 5 and 6 . Some of the results were calculated on a $24 \mathrm{~h}$ basis to facilitate comparison with results of earlier publications, although it was recognized that this may have introduced a substantial error. The changes in the amounts of constituents of digesta during passage along the intestine represent the balances between the inflows of digesta from the abomasum and the secretion of water and endogenous materials into the gut, on the one hand, and their absorption through the intestinal mucosa, on the other hand. The means, calculated by an 'incomplete block' analysis, showed that the cannulation site had a highly significant effect on the flow of digesta, dry matter and NPN, and a significant effect on that of total $\mathrm{N}$ and ammonia $\mathrm{N}$. The effect on $\alpha-\mathrm{NH}_{2}-\mathrm{N}$ came close to being significant. There were no significant differences between rams.

The amount of digesta passing the pylorus, 5 I I $\mathrm{g} / \mathrm{h}$ ( $12 \cdot 3 \mathrm{~kg} / 24 \mathrm{~h}$ ) (see Table 5) was similar to the mean amount reported by other authors (e.g. Nicholson \& Sutton, 1969), who kept sheep on a similar dietary regimen.

In agreement with the general experience of others (Hogan \& Phillipson, I960), it was observed that $40 \%$ of the digestible dry matter ingested reached the pylorus; the net loss of $60 \%$ was mainly digestible carbohydrate. Only $5 \%$ less $\mathrm{N}$ than the amount ingested reached the pylorus (Table 5 ).

The only part of the intestine in which substantial increases of water, dry matter and total $\mathrm{N}$ were found was the $\mathrm{I} \mathrm{m}$ section posterior to the pylorus, but the increase was statistically significant only for total $\mathrm{N}$. These increases were caused by the inflow of bile, and pancreatic and duodenal juices. The observed increase of about $44 \mathrm{~g} / \mathrm{h}$ in the flow is consistent with the reported daily rates of secretion of digestive juices by sheep, 
Table 7. Nitrogenous fractions expressed as a ratio of total nitrogen in the digesta of sheep, sampled at different sites of the intestinal tract

$\begin{array}{ccccccc}\begin{array}{c}\text { Distance of site } \\ \text { from pylorus }(\mathrm{m})\end{array} & \text { Protein } & \begin{array}{c}\text { Non- } \\ \text { protein N }\end{array} & \overbrace{\text { Bound }}^{\alpha-\mathrm{NH}_{2}-\mathrm{N}} & \text { Free } & \text { Ammonia } & \\ 0.5 & 0.667 & 0.333 & 0.164 & 0.078 & 0.070 & \text { Unaccounted N } \\ \text { I } & 0.649 & 0.35 \mathrm{I} & 0.146 & 0.064 & 0.066 & 0.02 \mathrm{I} \\ 3 & 0.622 & 0.378 & 0.216 & 0.090 & 0.064 & 0.008 \\ 7 & 0.606 & 0.394 & 0.171 & 0.148 & 0.066 & 0.009 \\ 15 & 0.681 & 0.319 & 0.047 & 0.183 & 0.067 & 0.022 \\ 25 & 0.772 & 0.228 & 0.094 & 0.092 & 0.065 & 0.022\end{array}$

namely bile $700 \mathrm{ml}$ (Harrison, I962), pancreatic juice 300-400 $\mathrm{ml}$ (Magee, I961; Taylor, 1962), duodenal juice $500 \mathrm{ml}$ (Harrison \& Hill, I962).

In the sections of the intestine from $\mathrm{I}$ to $\mathrm{I} 5 \mathrm{~m}$ posterior to the pylorus, however, the amounts of water, dry matter and total $\mathrm{N}$ decreased gradually as a result of their absorption through the intestinal wall. The region of the intestine situated at a distance of $7^{-1} 5 \mathrm{~m}$ from the pylorus was more active with respect to the absorption of $\mathrm{N}$ compounds, whereas water and dry matter were absorbed to a greater extent in the section $\mathrm{I}-7 \mathrm{~m}$ from the pylorus (Tables 5 and 6 ). Only very small changes in the amounts of water, dry matter and total $\mathrm{N}$ occurred in the lower part of the intestine (between 15 and $25 \mathrm{~m}$ distant from the pylorus).

$p H$. The $\mathrm{pH}$ of the intestinal contents sampled at the pylorus fluctuated between $2 \cdot 6$ and $3 \cdot 0$, increased gradually along the intestine, but remained acid even at a distance of more than $7 \mathrm{~m}$ from the pylorus. This agrees with $\mathrm{pH}$ measurements made by Lennox \& Garton (I968). The fluctuations of the $\mathrm{pH}$ values measured in different samples from the same sites of the intestine resulted from the changes in the $\mathrm{pH}$ during the day and did not show any regular trend.

$N$-containing fractions. The amounts of $\mathrm{N}$ and $\mathrm{N}$-containing constituents of the digesta passing the different sites of the intestine are presented in Table 6, and the composition of these $\mathrm{N}$-containing fractions is given in Table 7 .

The net daily increases found beyond the entry of the common bile duct were $2.7 \mathrm{~g}$ protein $\mathrm{N}$ and $2 \cdot 0 \mathrm{~g}$ NPN. These were the amounts secreted by one sheep (Table 6 ). The increase in the NPN content of the digesta in the uppermost region of the intestine, that is the section immediately distal to the pylorus, indicates the presence of non-protein amino acids in the endogenous secretions.

Whereas the amounts of total $\mathrm{N}$ decreased considerably at a distance of $\mathrm{I}-7 \mathrm{~m}$ from the pylorus, the amounts of NPN remained fairly constant in this region, unlike those of free $\alpha-\mathrm{NH}_{2}-\mathrm{N}$, which increased slightly. This tendency indicates that the rate of proteolysis exceeds the rate of absorption of its products, which obviously occurs as free amino acids. The amounts of total $\mathrm{N}$ and of all $\mathrm{N}$-containing fractions decreased considerably in the section $7^{-1} 5 \mathrm{~m}$ distant from the pylorus, the area of most intensive $\mathrm{N}$ absorption. The decrease of bound $\alpha-\mathrm{NH}_{2}-\mathrm{N}$ in the area 7-15 m distant from the pylorus may have resulted from the action of exopeptidases. The highest percentage of free $\alpha-\mathrm{NH}_{2}-\mathrm{N}$ was found at a distance of $\mathrm{I} 5 \mathrm{~m}$ from the pylorus (Table 7 ). 


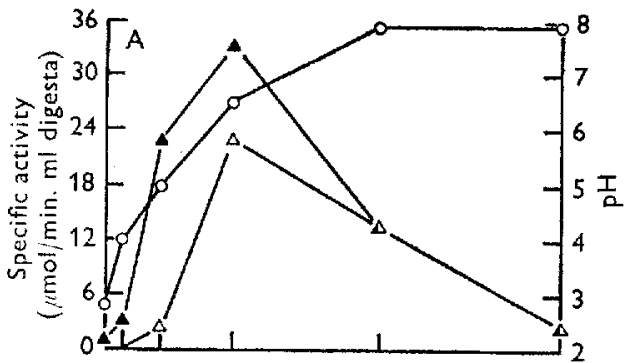

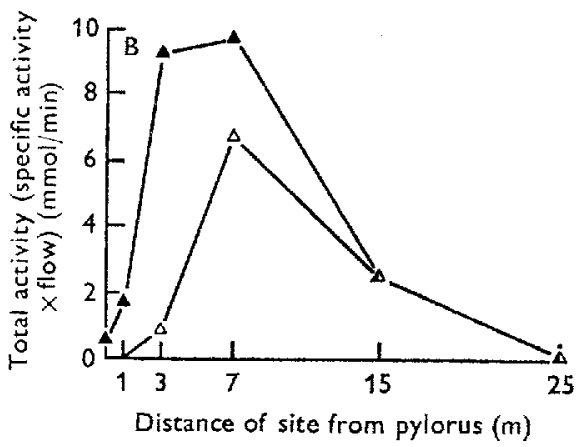

Fig. I

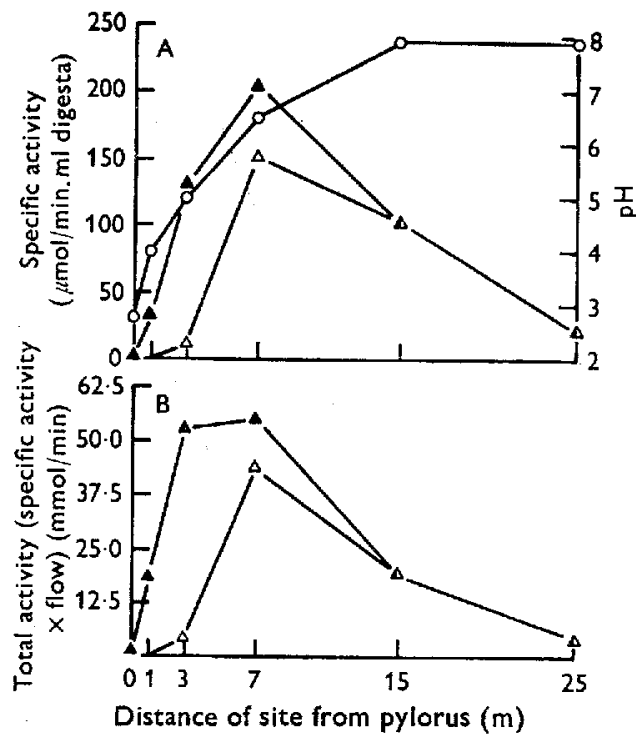

Fig. 2

Fig. 1. Trypsin activity in the digesta of sheep, sampled at different sites of the intestine. $\triangle$, trypsin activity at $\mathrm{pH}$ in situ; $\boldsymbol{\Lambda}$, trypsin activity at optimal $\mathrm{pH}(\mathrm{pH} 8 \cdot 0) ; 0, \mathrm{pH}$ in situ.

Fig. 2. Chymotrypsin activity in the digesta of sheep, sampled at different sites of the intestine. $\triangle$, chymotrypsin activity at $\mathrm{pH}$ in situ; $\Delta$, chymotrypsin activity at optimum $\mathrm{pH}(\mathrm{pH} 8 \cdot 0)$; $O, \mathrm{pH}$ in situ.
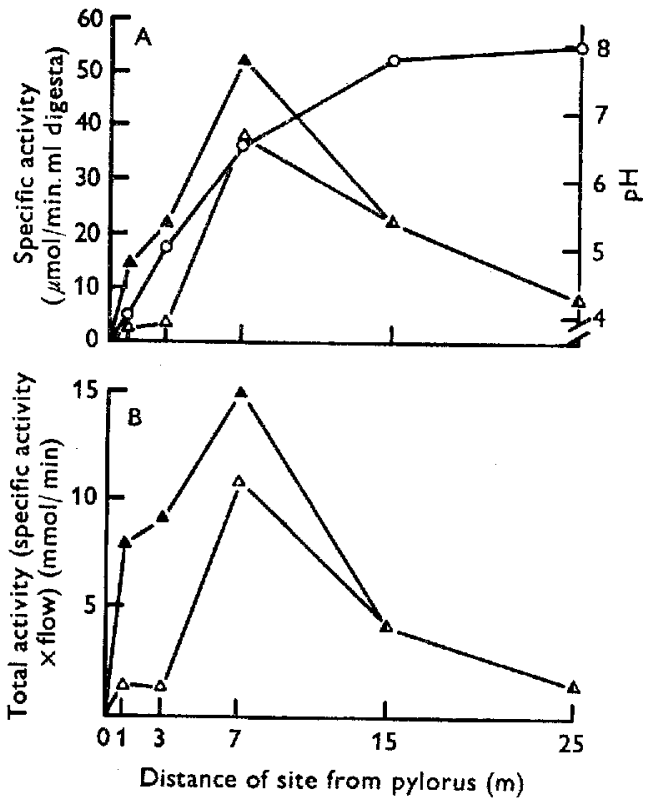

Fig. 3. Carboxypeptidase $A$ activity in the digesta of sheep, sampled at different sites of the intestine. $\triangle$, carboxypeptidase $A$ activity at $\mathrm{pH}$ in situ; $\mathbf{\Delta}$, carboxypeptidase $\mathrm{A}$ activity at optimum $\mathrm{pH}(\mathrm{pH} 7 \cdot 6) ; \mathrm{O}, \mathrm{pH}$ in situ. 


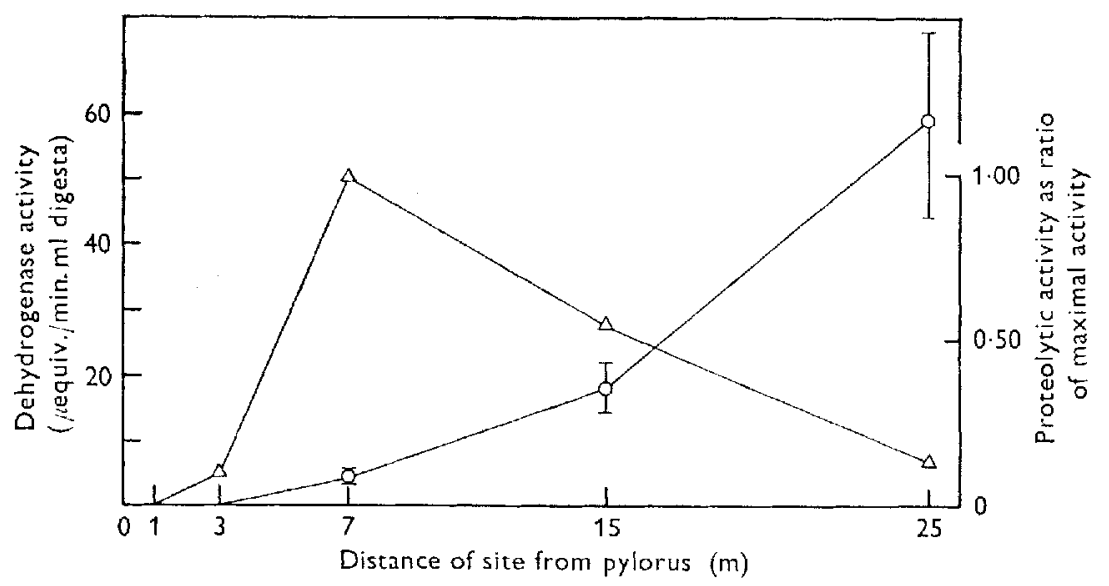

Fig. 4. Dehydrogenase and proteolytic activities in digesta of sheep sampled at different sites of the intestine. $O$, dehydrogenase activity; $\triangle$, proteolytic activities are mean values of the sum of trypsin, chymotrypsin and carboxypeptidase A activities (expressed as ratio of maximal activity found at $7 \mathrm{~m}$ distance from the pylorus).

The nitrogenous components of the digesta contain also an unidentified fraction, which includes hexosamines (Badawy \& Mackie, 1964) and nucleic acids (Smith \& McAllan, 1971). The highest percentage of this unidentified fraction was found in the upper section of the intestine proximate to the entry of the common bile duct.

The small losses of $\mathrm{N}$ found in the large intestine were due to the absorption of ammonia from the caecum, as shown by McDonald (1948), whereas the absorption of amino acids from the caecum is unlikely, since they would be destroyed there by bacterial enzymes (Clarke, Ellinger \& Phillipson, 1966).

Proteolytic activities. The activities of the proteolytic enzymes trypsin, chymotrypsin and carboxypeptidase $\mathrm{A}$ were examined in samples taken from different sites of the intestine, and the measurements were made at the actual $\mathrm{pH}$ (in situ) and at the $\mathrm{pH}$ of optimal activity of the three enzymes. The activities of samples withdrawn at three different time-intervals after the morning feed differed only slightly and did not show any regular trend. The results presented in Figs. I, 2 and 3 were based on average values of activities determined at three different times of the day. Samples taken I $\mathrm{m}$ distant from the pylorus showed very low trypsin or chymotrypsin activities, at the $\mathrm{pH}$ in situ and also at the optimum $\mathrm{pH}$.

Since the conversion of the zymogens into active enzymes takes place above $\mathrm{pH} 5$, the proteolytic activities increase only slowly along the intestine (even when measured at the optimum $\mathrm{pH}$ ) and maximum activity of these enzymes is reached in the samples withdrawn at a distance of $7 \mathrm{~m}$ from the pylorus; since the $\mathrm{pH}$ of the digesta increases along the intestine, the difference between the activities measured at the actual and optimum $\mathrm{pH}$ became smaller in the sample taken at the site $7 \mathrm{~m}$ distant from the pylorus and disappeared in those taken in the lower regions of the intestine. The decrease in activities of all three enzymes in the lower regions of the intestine may be attributed to inactivation of these enzymes in the more alkaline medium. 
Table 8. Amounts (mmol/h) of total amino acids present in the feed, passing through different sites of the intestine and excreted in the faeces of sheep

\begin{tabular}{|c|c|c|c|c|c|c|c|c|}
\hline \multirow[b]{2}{*}{ Amino acid } & \multirow{2}{*}{$\operatorname{In}_{\text {feed }}$} & \multicolumn{6}{|c|}{ In digesta at distance from pylorus of $(m)$} & \multirow{2}{*}{$\begin{array}{c}\text { In } \\
\text { faeces }\end{array}$} \\
\hline & & 0.05 & $\mathbf{I}$ & 3 & 7 & I 5 & 25 & \\
\hline \multicolumn{9}{|l|}{ Essential: } \\
\hline Threonine & I.39 & $x \cdot 86$ & $2 \cdot I I$ & $I \cdot 76$ & $1 \cdot 58$ & 0.75 & 0.77 & 0.62 \\
\hline Valine & 2.55 & 3.08 & $3 \cdot 51$ & $3 \cdot 06$ & 2.54 & $I \cdot 22$ & $I \cdot 19$ & I.06 \\
\hline Methionine & 0.31 & 0.61 & 0.76 & 0.68 & 0.60 & 0.27 & 0.28 & 0.23 \\
\hline Isoleucine & $\mathbf{I} \cdot 39$ & I.44 & $2 \cdot 03$ & $\mathbf{1} 77$ & $I \cdot 39$ & 0.63 & 0.61 & 0.59 \\
\hline Leucine & 2.66 & $2 \cdot 11$ & 3.05 & $2 \cdot 50$ & $2 \cdot 00$ & 0.86 & 0.88 & 0.86 \\
\hline Phenylalanine & $\mathrm{I} \cdot 53$ & $I \cdot 47$ & +69 & $1 \cdot 54$ & $I \cdot 30$ & 0.67 & 0.53 & 0.66 \\
\hline Lysine & $\mathbf{1} \cdot \mathbf{2 3}$ & $x \cdot 65$ & $2 \cdot 33$ & 2.06 & $\mathrm{r} 58$ & 0.47 & 0.58 & 0.60 \\
\hline Histidine & 0.55 & 0.50 & 0.48 & 0.50 & 0.45 & 0.21 & $0 \cdot 18$ & 0.20 \\
\hline Arginine & $I \cdot 20$ & 0.87 & $1 \cdot 29$ & I'II & $0.8 \mathrm{I}$ & 0.30 & 0.36 & 0.32 \\
\hline Total & 12.8 & 13.6 & $17 \cdot 3$ & $15^{\circ}$ & $12 \cdot 3$ & $5 \cdot 3^{8}$ & $5 \cdot 38$ & $5^{\circ} \mathrm{I} 4$ \\
\hline \multicolumn{9}{|l|}{ Non-essential: } \\
\hline Aspartic acid & $3 \cdot 17$ & 3.40 & $3 \cdot 95$ & 3.49 & $2 \cdot 96$ & $r \cdot 26$ & $I \cdot 30$ & $I \cdot I I$ \\
\hline Serine & $r \cdot 72$ & $I \cdot 3 I$ & $2 \cdot 30$ & 1.91 & $x \cdot 80$ & 0.77 & $0.8 \mathrm{r}$ & 0.64 \\
\hline Glutamic acid & $4 \cdot 45$ & $2 \cdot 98$ & $4 \cdot 37$ & 3.94 & $2 \cdot 65$ & $1 \cdot 36$ & $I \cdot 42$ & $I \cdot 22$ \\
\hline Proline & 3.07 & $I * 46$ & $2 \cdot 30$ & $1 \cdot 72$ & $\mathrm{I} \cdot 55$ & 0.77 & 0.66 & 0.90 \\
\hline Glycine & 3.02 & $2 \cdot 80$ & $6 \cdot 25$ & 5.06 & 3.65 & 3.07 & $I \cdot 54$ & $I \cdot 36$ \\
\hline Alanine & $2 \cdot 83$ & $2 \cdot 59$ & 3.66 & $3 \cdot 17$ & $2 \cdot 5^{x}$ & $1 \cdot 15$ & $I \cdot 2 \mathrm{r}$ & I. IO \\
\hline Cystine + cysteine & 0.31 & 0.30 & 0.62 & 0.34 & 0.41 & 0.24 & 0.16 & 0.17 \\
\hline Tyrosine & $I \cdot 27$ & $I \cdot 12$ & $I-72$ & $x \cdot 46$ & $\mathrm{I} \cdot 07$ & 0.58 & 0.32 & 0.23 \\
\hline Total & 19.9 & $16 \cdot 0$ & $25 \cdot 2$ & $2 I \cdot I$ & $x 6 \cdot 6$ & $9 \cdot 20$ & $7 \cdot 42$ & 6.73 \\
\hline
\end{tabular}

Dehydrogenase activity. An increase of the dehydrogenase activity was observed in the lower part of the intestine (Fig. 4).

Amino acids. The rate of flow of total amino acids through the different sections of the intestines of sheep is given in Table 8, that of non-protein amino acids in Table 9 and that of amino acids bound as protein in Table ro. The values in Table 9 were obtained by hydrolysis of TCA filtrates of digesta and represent the sum of amino acids present in free form and as peptides. The results concerning the flow of amino acids present as proteins given in Table to were obtained by subtraction of the values for non-protein amino acids (Table 9) from those for total amino acids (Table 8). Individual amino acids were determined in pooled samples. The trend in their changes along the intestine agreed with those of total $\mathrm{N}$ and NPN, which were found to be highly significant (see Table 6). The amino acids designated as 'essential' in this work are those required by the growing rat, since, according to other authors, the same amino acids are also essential for the tissue metabolism of ruminant animals (see Coelho da Silva, Seeley, Thomson, Beever \& Armstrong, 1972).

There was a net loss of non-essential amino acids between the mouth and the pylorus; it was considerable for glutamic acid, proline and serine. The total amount of amino acids reaching the small intestine was smaller than that of the ingested amino acids, and the quantity of amino acids lost in the rumen exceeded the amount synthesized there. The $100 \%$ increase in methionine during the passage of the food through the reticulo-rumen is comparatively high, but agrees with the results of other authors (Conrad, Miles \& Butdorf, I967), who reported the biosynthesis of considerable 
Table 9. Amounts (mmol/h) of non-protein amino acids in digesta of sheep passing through different sites of the intestine

Amino acid

Essential:

'Ihreonine

Valine

Methionine

Isoleucine

Leucine

Phenylalanine

Lysine

Histidine

Arginine

Total

Non-essential:

Aspartic acid

Serine

Glutamic acid

Proline

Glycine

Alanine

Cystine + cysteine

Tyrosine

'I'otal
At distance from pylorus of $(\mathrm{m})$

\begin{tabular}{|c|c|c|c|c|c|}
\hline 0.05 & I & 3 & 7 & $\mathrm{r}_{5}$ & 25 \\
\hline 0.75 & 0.76 & 0.92 & $0.9 \mathrm{r}$ & $0.3^{8}$ & 0.26 \\
\hline 1.00 & $I \cdot 06$ & $I \cdot 24$ & $\mathrm{I} \cdot \mathrm{I} \mathrm{I}$ & 0.50 & 0.28 \\
\hline 0.23 & 0.27 & 0.31 & 0.21 & O.II & 0.08 \\
\hline 0.54 & 0.55 & 0.69 & 0.75 & 0.19 & 0.12 \\
\hline $\begin{array}{r}.17 \\
0.90\end{array}$ & 0.86 & I.04 & 0.91 & 0.37 & 0.19 \\
\hline 0.59 & 0.57 & 0.70 & 0.68 & 0.29 & 0.21 \\
\hline 0.80 & 0.88 & I'IO & 1.02 & 0.32 & 0.15 \\
\hline 0.13 & 0.16 & 0.19 & $0.1 \mathrm{r}$ & 0.10 & 0.05 \\
\hline $0 \cdot 34$ & 0.35 & 0.46 & 0.42 & O.II & 0.05 \\
\hline $5 \cdot 28$ & $5 \cdot 46$ & 6.65 & 6.12 & $2 \cdot 37$ & I 39 \\
\hline$x \cdot 36$ & $I \cdot 4 T$ & 1.74 & $I \cdot 78$ & 0.60 & 0.40 \\
\hline 0.71 & 0.76 & 0.90 & 0.86 & 0.40 & 0.24 \\
\hline I 37 & I. 53 & 2.01 & $I \cdot 96$ & 0.73 & 0.40 \\
\hline 0.60 & 0.66 & 0.65 & 0.69 & 0.28 & 0.23 \\
\hline 1.02 & $\mathrm{I} \cdot 34$ & I. 59 & $2 \cdot 15$ & 1.40 & 0.36 \\
\hline$I \cdot 28$ & $1 \cdot 29$ & I'59 & $\mathrm{t} \cdot 30$ & 0.54 & 0.34 \\
\hline 0.07 & 0.13 & 0.08 & 0.10 & 0.07 & 0.04 \\
\hline 0.63 & 0.81 & 0.89 & 0.80 & 0.42 & 0.29 \\
\hline 7.04 & 7.93 & 9.45 & $9 \cdot 64$ & 4.44 & 2.30 \\
\hline
\end{tabular}

Table 10. Amounts (mmol/h) of protein amino acids in digesta of sheep passing through different sites of the intestine

At distance from pylorus of $(m)$

\begin{tabular}{|c|c|c|c|c|c|c|}
\hline Amino acid & 0.05 & I & 3 & 7 & I 5 & 25 \\
\hline \multicolumn{7}{|l|}{ Fssential: } \\
\hline Threonine & I. II & $\mathrm{I} \cdot 34$ & 0.84 & 0.67 & 0.37 & 0.51 \\
\hline Valine & $2 \cdot 08$ & $2 \cdot 45$ & $1 \cdot 82$ & $I \cdot 43$ & 0.72 & $0.9 \mathrm{I}$ \\
\hline Methionine & 0.38 & 0.48 & 0.37 & 0.39 & 0.15 & 0.20 \\
\hline Isoleucine & 0.90 & $\mathrm{I} \cdot 47$ & $\mathrm{I} \cdot 08$ & 0.65 & 0.44 & 0.49 \\
\hline I.eucine & $1 \cdot 21$ & $2 \cdot 18$ & $1 \cdot 52$ & $T \cdot 09$ & $0 \cdot 49$ & 0.69 \\
\hline Phenylalanine & 0.88 & $I \cdot I I$ & 0.84 & 0.62 & $0 \cdot 39$ & 0.32 \\
\hline Lysine & 0.85 & $I \cdot 46$ & 0.95 & 0.56 & 0.15 & 0.43 \\
\hline Histidine & 0.36 & 0.33 & $0.3 I$ & 0.33 & $0.1 \mathrm{I}$ & 0.13 \\
\hline Arginine & 0.52 & 0.95 & 0.65 & 0.40 & 0.18 & 0.30 \\
\hline 'Total & $8 \cdot 29$ & $11 \times 77$ & $8 \cdot 38$ & $6 \cdot 14$ & 3.00 & 3.98 \\
\hline \multicolumn{7}{|l|}{ Non-essential: } \\
\hline Aspartic acid & $2 \cdot 03$ & $2 \cdot 55$ & $\mathrm{I} 75$ & $I \cdot I 8$ & 0.67 & 0.90 \\
\hline Serine & 0.61 & $1 \cdot 56$ & $I \cdot O I$ & 0.94 & $0.3^{8}$ & 0.58 \\
\hline Glutamic acid & $1 \cdot 61$ & $2 \cdot 83$ & $1 \cdot 93$ & 0.69 & 0.63 & I.OI \\
\hline Proline & $0-86$ & $\mathbf{x} 64$ & 1.07 & 0.86 & 0.49 & 0.43 \\
\hline Glycine & $1 \cdot 78$ & $4 \cdot 92$ & $3 \cdot 48$ & $I \cdot 50$ & +67 & $\mathrm{I}=\mathrm{I} 8$ \\
\hline Alanine & $1 \cdot 32$ & $2 \cdot 34$ & $\mathrm{I} \cdot 59$ & $I \cdot 22$ & 0.61 & 0.88 \\
\hline Cystine + cysteine & 0.22 & 0.49 & 0.26 & 0.31 & 0.17 & 0.13 \\
\hline Tyrosine & 0.48 & $0.9 \mathrm{I}$ & 0.57 & 0.27 & 0.17 & 0.03 \\
\hline Total & $8=91$ & $17 \cdot 24$ & $1 x \cdot 66$ & 6.97 & 472 & $5 \cdot 14$ \\
\hline
\end{tabular}


Table I I. Ratio of free to bound $\alpha-\mathrm{NH}_{2}-$ nitrogen in digesta of sheep sampled at different sites of the intestinal tract

$\begin{array}{cc}\begin{array}{c}\text { Distance of site } \\ \text { from pylorus (m) }\end{array} & \text { Ratio } \\ 0.50 & 0.48 \\ \text { I } & 0.44 \\ 3 & 0.43 \\ 7 & 0.87 \\ 15 & 3.84 \\ 25 & 1.89\end{array}$

amounts of methionine in the rumen. The proportions of essential amino acids were slightly higher in the digesta reaching the intestines than in the food ingested. This improvement in the amino acid pattern of food proteins brought about by ruminal action agrees with observations of other authors (Neudoerffer, Leadbeater, Horney \& Bayley, I97I; Potter, McNeill \& Riggs, I97I).

Between one-third and one-half of most amino acids entered the intestine as nonprotein amino acid (free- and peptide-bound), but the percentage was much lower for histidine, arginine, proline and cystine (Tables 8 and 9).

The rate of flow of almost all individual amino acids was increased in the section $\mathrm{I} \mathrm{m}$ posterior to the pylorus owing to pancreatic, duodenal and biliary secretions. Their endogenous influx into the uppermost region of the intestine contained mainly proteins and only small amounts of non-protein amino acids. The influx of endogenous juices contributes more non-essential amino acids than essential ones. The very high increase in the flow of glycine $(250 \%)$ in the region between 0.05 and $x \mathrm{~m}$ distant from the pylorus has to be attributed mainly to the secretion of glycocholic acid, an important constituent of bile acids, and only to a comparatively small extent to endogenous protein (see Nixon \& Mawer, 1970).

The changes in rate of flow in the sections between $\mathrm{I}$ and $\mathrm{r}_{5} \mathrm{~m}$ distance from the pylorus, measured by analysis of individual amino acids (see Table 8 ), showed the same trend as that of $\mathrm{N}$ and $\mathrm{NH}_{2}$ groups. In the sections between $\mathrm{I}$ and $3 \mathrm{~m}$ and between 3 and $7 \mathrm{~m}$ distant from the pylorus there were considerable decreases $(3 \mathrm{I} \%$ and $34 \%$ respectively) in the rate of flow of protein-bound amino acids (Table Io), whereas the rate of flow of non-protein amino acids was increased by $20 \%$ in the region between $\mathrm{I}$ and $3 \mathrm{~m}$ and did not change in that between 3 and $7 \mathrm{~m}$ (Table 9). It might be concluded from these findings that in both these regions the extent of proteolysis exceeded that of absorption. The fate of $\mathrm{N}$ compounds in the section $7^{-15} \mathrm{~m}$ distant from the pylorus differed substantially from that in both preceding sections. The relatively greater decrease in non-protein amino acids ( $57 \%$ ) compared with that of protein amino acids ( $4 \mathrm{I} \%$ ) that occurred in this region showed that this is an area of intensive absorption of amino acids. The rate of flow of some individual amino acids, such as lysine, decreased here by as much as $70 \%$, while a preferential absorption of essential amino acids was apparent.

The total amount of amino acids (protein and non-protein, Table 8) showed almost no change during passage of the digesta through the lower section of the intestine, 


\section{I38 D. Ben-Ghedalia, H. Tagari, A. Bondi and A. Tadmor 1974}

$15^{-25} \mathrm{~m}$ distant from the pylorus. In the lower part of the intestine the dehydrogenase activity was considerably enhanced (Fig. 4).

A few individual amino acids, among them glycine, tyrosine and cysteine, showed changes in the rate of flow in the section of the intestine $15^{-25} \mathrm{~m}$ posterior to the pylorus. Glycine decreased by as much as $50 \%$ during passage through the lower part of the intestine. 'This decrease in glycine might be attributed in great part to reabsorption of bile acids from the lower small intestine (Garton, r969). The amounts of most individual amino acids excreted daily in the faeces were somewhat lower than the amounts leaving the terminal ileum (at $25 \mathrm{~m}$ distant from the pylorus). This decrease in the amino acid content of the digesta during their passage through the large intestine was apparently caused by the deaminase activity of caecal bacteria (Hecker, 197I). For some amino acids, such as isoleucine, histidine and cystine, the daily amounts passing through the terminal ileum were the same as those excreted in the faeces. The amounts of phenylalanine and proline excreted daily in the faeces exceeded the amounts leaving the terminal ileum.

\section{DISCUSSION}

Whereas digestible carbohydrates are degraded to a great extent in the rumen and their metabolites are absorbed through the rumen wall, the net loss of $\mathrm{N}$ may be very small in the reticulo-rumen; in this study the equivalent of $95 \%$ of the food $\mathrm{N}$ reached the pylorus. Microbial proteins formed by transformation of dietary proteins and undecomposed dietary proteins enter the intestinal tract, where the decisive steps in their digestion and absorption take place. It is remarkable that the amount of $\mathrm{N}$ present in the digesta increased considerably $(4.7 \mathrm{~g} / \mathrm{d})$ after the inflow of pancreatic juice and bile. Apart from their specific functions, these endogenous proteins may be a useful supplement to the dietary and microbial proteins reaching the intestinal tract, particularly when the diet is deficient in protein.

Some of our findings in this work concerning the extent and sites of proteolytic action occurring in the intestine, point to differences between ruminants and simplestomached animals. One of the reasons for these differences is that neutralization of the digesta entering the intestine is much slower in ruminants than in simple-stomached animals (Kay, 1969) and different $\mathrm{pH}$ values prevailing in corresponding sections of the intestine have a great influence on proteolytic activities. The increase in the ratio of $\alpha-\mathrm{NH}_{2}-\mathrm{NPN}$ to protein $\mathrm{N}$ (see Fig. 5) in samples taken $3 \mathrm{~m}$ distant from the pylorus compared with that in samples taken $\mathrm{I} \mathrm{m}$ distant must be attributed partly to the action of pepsin (unpublished results) which continues to act in the weakly acid medium of the upper intestine.

Because of the acidity persisting in the upper sections of the intestinal tract of the sheep, the transformation site of pancreatic zymogens into active enzymes is shifted slightly along the intestinal tract. The highest ratio of $\alpha-\mathrm{NH}_{2}-\mathrm{NPN}$ to protein $\mathrm{N}$ found at a distance of $7 \mathrm{~m}$ from the pylorus (Fig. 5) is consistent with our results from enzymic assays, which showed highest activities of trypsin, chymotrypsin and carboxypeptidase $A$ in samples taken at this site (Figs. $1-3$ ). As seen from Fig. 5, the ratio 


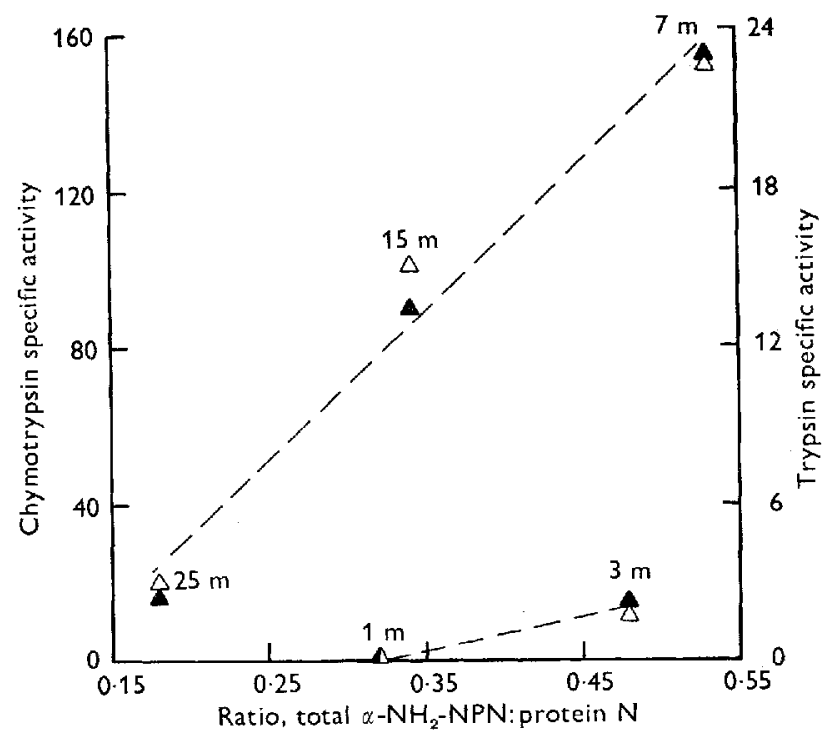

Fig. 5. Relationship between trypsin and chymotrypsin activities and the ratio of $\alpha-\mathrm{NH}_{2}-$ non-protein nitrogen to protein $\mathbf{N}$ in digesta of sheep. $\boldsymbol{\Delta}$, trypsin specific activity; $\Delta$, chymotrypsin specific activity.

between trypsin and chymotrypsin activities is always constant, and the parallel changes in these two enzymic activities are accompanied by corresponding changes in the ratio of $\alpha-\mathrm{NH}_{2}-\mathrm{NPN}$ to protein $\mathrm{N}$. In rats, unlike sheep, the amount of chymotrypsin relative to trypsin undergoes a progressive decrease along the small intestine (Pelot \& Grossman, 1962).

Unlike trypsin and chymotrypsin activities and the ratio of $\alpha-\mathrm{NH}_{2}-\mathrm{NPN}$ to protein $\mathrm{N}$, which are at a maximum at a distance of $7 \mathrm{~m}$ from the pylorus (Fig. 5 ), the ratio of free to bound $\alpha-\mathrm{NH}_{2}-\mathrm{N}$ increases gradually along the intestine over a distance of $\mathrm{I} 5 \mathrm{~m}$ from the pylorus (Table II). The increase in the latter ratio along the intestine originates apparently from the action of exopeptidases. In agreement with this conclusion, Symons \& Jones ( 1966 ) found a peak of activity of dipeptidases in the mid-ileum of the sheep.

According to our results (Tables 6 and 7), intensive absorption of $\alpha-\mathrm{NH}_{2}-\mathrm{N}$ takes place in the section between 7 and $15 \mathrm{~m}$ distant from the pylorus, but the exopeptidase activity seems to be even greater than that of the absorption, as can be seen from the high concentration of $\alpha-\mathrm{NH}_{2}-\mathrm{N}$, and the high ratio of free $\alpha-\mathrm{NH}_{2}-\mathrm{N}$ to bound $\mathrm{NH}_{2}-\mathrm{NPN}$ of the digesta sampled in the section between 7 and $15 \mathrm{~m}$ distant from the pylorus (Table II).

The results of this work indicate that the absorption of proteins (as amino acids) and of other nutrients occurs in the area of the intestine $\mathrm{I}-15 \mathrm{~m}$ posterior to the pylorus. Whereas absorption of amino acids takes place to a greater extent in the section $7-15 \mathrm{~m}$ distant from the pylorus, the absorption of other nutrients from the area between $\mathrm{I}$ and $7 \mathrm{~m}$ distant exceeds the extent of their absorption from the $7^{-1} 5 \mathrm{~m}$ section. Results agreeing with our work regarding the sites of absorption of amino acids were obtained 


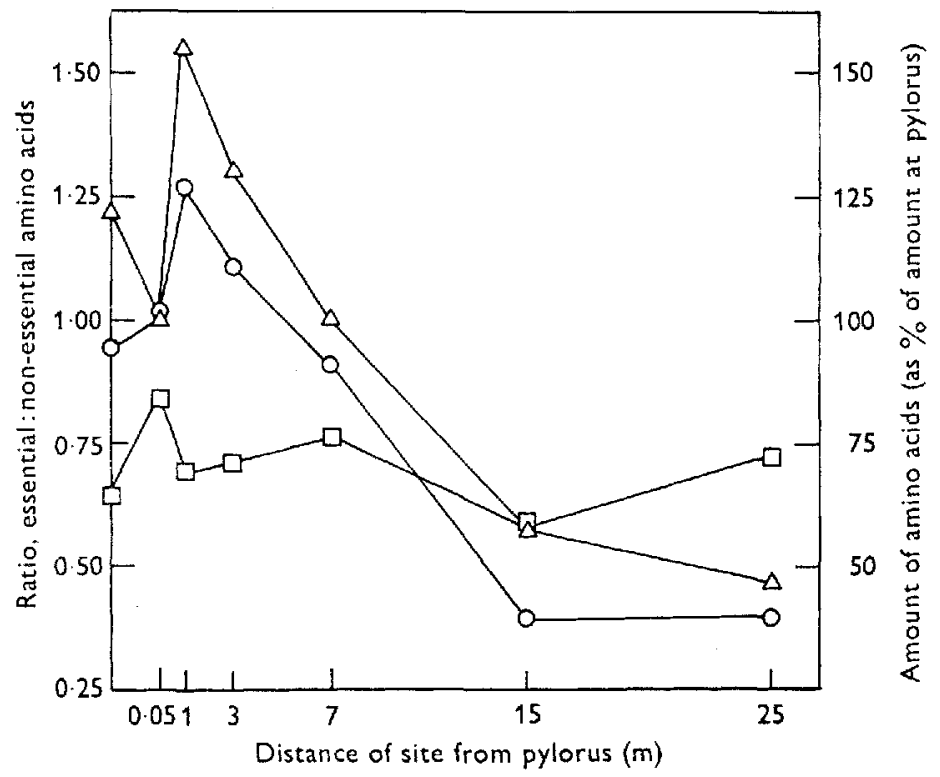

Fig. 6. Changes in the amounts of essential and non-essential amino acids and in the ratio of essential to non-essential amino acids in the digesta of sheep, sampled at different sites along the intestine. $O$, total essential amino acids; $\Delta$, total non-essential amino acids; $\square$, ratio of essential to non-essential amino acids.

by M. I. Chalmers \& F. White (private communication). These workers found that absorption of single amino acids, administered either intraruminally or into the abomasum, was maximum over the area drained by the mesenteric vein. The position of the mesenteric vein cannula used for sampling coincides with the area of absorption from the intestinal tract found in this work. Further, Neudoerffer, Duncan \& Horney (197 I) examined the sites of intestinal uptake of $\left[{ }^{14} \mathrm{C}\right]$ methionine by incubation in vitro with gut segments of cattle and, in agreement with our results, found that the duodenum and jejunum are the sites of absorption of $\left[{ }^{14} \mathrm{C}\right]$ methionine.

In agreement with the concepts of other authors (Clarke et al. 1966; Coelho da Silva et al. 1972), the supply of essential amino acids to the tissues of ruminant animals is somewhat improved compared with the amino acid composition of the diet. This trend is shown by the changes in the ratio of essential to non-essential amino acids along the intestinal tract, as seen in Fig. 6. This ratio was higher in the digesta which passed the rumen and reached the intestine than in the feed ingested, which indicates an improvement in protein quality, caused by ruminal biosynthesis of essential amino acids and microbial degradation of non-essential amino acids.

The supply of essential amino acids required for the tissue metabolism of the host animal is augmented also by preferential absorption through the intestinal wall. In the section of most intensive absorption, 7-15 $\mathrm{m}$ distant from the pylorus, the absorption of essential amino acids markedly exceeded that of non-essential amino acids; this is shown by the decrease in the ratio of essential to non-essential amino acids from 0.76 at $7 \mathrm{~m}$ distant to 0.58 at $15 \mathrm{~m}$ distant from the pylorus. As a net result, $60.5 \%$ of the 
essential amino acids passing through the pylorus and $43 \%$ of the non-essential amino acids were absorbed by the time the digesta had reached the site in the intestine $\mathrm{I} 5 \mathrm{~m}$ distant from the pylorus. The very efficient absorption of the essential amino acids, such as methionine, lysine and threonine, in this region (Tables 8 and ro) is of great benefit to ruminants, since under different feeding conditions limiting amounts of these amino acids reach the tissues of the host animal.

The fate of nitrogenous compounds passing the lower intestine ( $15-25 \mathrm{~m}$ distant from the pylorus) was different from that in the higher sections of the intestine, because of inactivation of proteolytic enzymes and enhanced bacterial activity in the lower sections. Since the amounts of essential amino acids did not change in the region between 15 and $22 \mathrm{~m}$ distant from the pylorus and those of non-essential amino acids decreased, the ratio of essential to non-essential amino acids increased.

The increase in the amounts of characteristic bacterial metabolites such as $\alpha$-aminoisobutyrate and of $\alpha, \epsilon$-diaminopimelic acid in the lower parts of the ileum, as reported by Harrison, Beever \& Thomson (197I) and by Mason \& White (I97r), provide further evidence for bacterial activity in the lower intestine. It appears from Fig. 4, that the microbial activity increases considerably in those lower parts of the intestine where the activity of proteolytic enzymes is limited because of their inactivation (Phillipson, 197I).

Biosynthetic activities of the caecal bacteria apparently balanced the loss of some amino acids or even caused an increase in others. The biosynthesis of amino acids and proteins by the caecal microflora lacks nutritional significance and no differentiation was made therefore between free and bound faecal amino acids.

The net changes in the composition of amino acids in the digesta between entrance and exit from the intestine observed in the present work are in general agreement with the results reported by Clarke et al. (1966) and Coelho da Silva et al. (1972). These earlier authors used sheep equipped with two fistulas in the proximal duodenum and the terminal ilcum. In the present work a clearer picture has been obtained of the sites at which proteolysis and absorption of amino acids occur, and of the relative extents of absorption of essential and non-essential amino acids. This was made possible by the use of sheep equipped with two or three fistulas which involved six different sites in the intestine and separation of protein and NPN amino acids in the digesta passing through the intestine.

The authors gratefully acknowledge the advice of Dr A. Gnizi on the statistical analysis, and the helpful assistance of Mr S. Zamwel.

\section{REFEREN CES}

Badawy, A. M. \& Mackie, W. S. (1964). Q. $\mathscr{H}$ exp. Physiol. 49, 356.

Clare, N. T. \& Stevenson, A. E. (1964). N.Z. $f l$ agric. Res. 7, 198.

Clarke, E. M. W., Ellinger, G. M. \& Phillipson, A. T. (1966). Proc. R. Soc. B x66, 63.

Coelho da Silva, J. F., Seeley, R. C., Thomson, D. J., Beever, D. E. \& Armstrong, D. G. (I972). Br. F. Nutr. 28, 43 .

Conrad, H. R., Miles, R. C. \& Butdorf, J. (1967). F. Nutr. 91, 337.

Corbett, J. L., Greenhalgh, J. F. D., McDonald, I. \& Florence, E. (I960). Br. F. Nutr. 14, 289. 


\section{I42 D. Ben-Ghadalia, H. Tagari, A. Bondi and A. Tadmor 1974}

Corse, D. A. \& Sutton, J. D. (I971). Proc. Nutr. Soc. 30, I8A.

Dror, Y., Tagari, H. \& Bondi, A. (1970). Y. agric. Sci, Camb. 75, 381 .

Garton, G. A. (1969). Proc. Nutr. Soc. 28, I3I.

Harrison, F. A. (Ig62). F. Physiol., Lond. 162, 212.

Harrison, D. G., Beever, D. E. \& Thomson, D. J. (Iy7I). Proc. Nutr. Soc. 30, I6 A.

Harrison, F. A. \& Hill, K. J. (r962). F. Physiol., Lond. r62, 225.

Hecker, I. F. (I97I). Br. J. Nutr. 25, 85 .

Hogan, J. P. \& Phillipson, A. T. (1960). Br. F. Nutr. x4, I47.

Kay, R. N. B. (1969). Proc. Nutr. Sac. 28, r40.

Klooster, A. Th. van't, Rogers, P. A. M. \& Sharma, H. R. (1969). Neth. 7. agric. Sci. 17, 60.

Lennox, A. M. \& Garton, G. A. (r968). Br. F. Nutr. 22, 247.

McDonald, I. W. (1948). Biochem. F. 42, 584 .

MacRae, J. C. \& Armstrong, D. G. (т969). Br. J. Nutr. 23, I5.

Magee, D. F. (т66т). \%. Physiol., Lond. r58, г32.

Marchaim, U. \& Kulka, R. G. (Ig67). Biochim. biophys. Acta 146, 553.

Mason, V. C. \& White, F. (r97x). Proc. Nutr. Soc. 30, I7 A.

Neudoerffer, T. S., Duncan, D. B. \& Horney, F. D. (I97I). Br. F. Nutr. 25, 333 .

Neudoerffer, T. S., Leadbeater, I'. A., Horney, F. D. \& Bayley, H. S. (197 I). Br. F. Natr. $25,343$.

Neurath, H. \& Schwert, G. W. (I050). Chem. Rew. 46, 69.

Nicholson, J. W. G. \& Sutton, J. D. (1969). Br. Y. Nutr. 23, 585 .

Nixon, S. E. \& Mawer, G. E. (1970). Br. Y. Nutr. 24, 227.

Pelot, D. \& Grossman, M. I. (1962). Am. J. Physiol. 202, 285.

Phillipson, A. T. (x97 I). Proc. Nutr. Soc. 30, 6I.

Potter, G. D., McNeill, J. W. \& Riggs, J. K. (I971). 7. Anim. Sci. 32, 540.

Rosen, H. (1957). Archs Biocheme. Biophys. 67, 10.

Smith, R. H. \& McAllan, A. B. (197 I). Br. F. Nutr, 25, г8 .

Stevenson, A. E. \& de Langen, H. (1960). N.Z. Fl agric. Res. 3, 3 I4.

Symons, L. E. A. \& Jones, W. O. (1 966). Comp. Biochem. Physiol. 18, 7 x.

'Tagati, H., Oror, Y., Ascarelli, I. \& Bondi, A. (Ig64). Br. F. Nutr. 18, 333.

Taylor, R. B. (Ig62). Res. vet. Sci. 3,63. 